\title{
Features of the Professional and Motivating Training Content Design for Students Majoring in "Tourism"
}

\author{
Tatyana Borisovna Lisitzina ${ }^{1}$, Adeliya Vadimovna Pavlova ${ }^{2}$, Rimma Rostyamovna Khanmurzina ${ }^{3}$, Valentina \\ Nikolayevna Vlasova ${ }^{4}$, Nikolai Aleksandrovich Chitalin ${ }^{5}$, Ilya Nikolayevich Maksimov ${ }^{5}$ \& Venera \\ Gilmkhanovna Zakirova ${ }^{5}$ \\ ${ }^{1}$ Gzhel State Art and Industry Institute, Russia \\ ${ }^{2}$ Volga Region State Academy of Physical Culture, Sport and Tourism, Russia \\ ${ }^{3}$ Kazan Cooperative Institute (Branch) of the Russian University of Cooperation, Russia \\ ${ }^{4}$ Institute of Technology Branch of Ulyanovsk State Agricultural Academy named after P.A. Stolypin, Russia \\ ${ }^{5}$ Kazan Federal University, Russia \\ Correspondence: Tatyana Borisovna Lisitzina, Ramensky region, Elektroizolyator, 67, 140155, Russian \\ Federation. E-mail: tat2254@yandex.ru
}

Received: September 22, 2014 Accepted: October 10, 2014 Online Published: December 2, 2014

doi:10.5539/ass.v11n1p148

URL: http://dx.doi.org/10.5539/ass.v11n1p148

\begin{abstract}
The urgency of the problem is based on the fact that professional motivating training of students majoring in "Tourism" should be primarily aimed at the formation of their orientation to the professional activity in the field of tourism. A key element of this training is its content, aimed at maintaining the interests of students and the predisposition to their chosen profession. The paper presents the content design features of professional and motivating training of students majoring in "Tourism" in the region with well-developed folk arts and crafts on the theoretical, regulatory, educational, personal levels and on the level of tourist activity. The article submission may be useful for teachers in selecting and structuring the content of professional and motivating training of students majoring in "Tourism".
\end{abstract}

Keywords: content design features, the selection and structuring of content, professional and motivating training, students, "Tourism" specialty, regional features

\section{Introduction}

Under a professional tourist activity in this study we mean a process, which is implemented due to the motivation in a tourist activity, formed on the basis of subject-object and subject-subject relationship. Among the subjects we include specialists from a tourism sector (tour operators, travel agents, tour guides, hotel industry workers, etc.), and other professionals included in the tourist infrastructure (medical staff, the transport sector and others.), consumers of tourism services (day visitors and tourists). The objects are the tourist resources of the region (climatic, historical and architectural, etc.), accommodation facilities (inns, hotels, boarding houses, motels, etc.) and food facilities (restaurants, cafes, bars, etc.), vehicles, means for leisure organization and others.

The purpose of professional and motivating training is to direct to the professional activity in the field of tourism, identifying the motivations and interests of students and predisposition to their avocation.

The motive of a professional activity is a conscious impulse to a specific form of this type of activity associated with the students' internal personal relationship to it (Ilyin, 2004, 2002; Kibanov, 2001; Popov \& Kondratyeva, 1999; Verbitsky \& Bakshaeva, 1998). Motives of professional activity are formed when students correlate their needs and capabilities with training disciplines, which are components of the tourist activity.

A number of studies considered the motive of action and the ways of its formation (Vishtak, 2003; Valeev, 2003; Ilkevich \& Ilkevich, 2013; Sorokina, 2003; Zhdanova, 2012). Numerous studies (Bugrimenko, 2006; Dubovitskaya, 2003; Gribenyuk \& Gribenyuk, 1998; Khan, 2009) have shown that exactly the way of formation of professional motivation through training activities is the most effective, and nature of motivation can be programmed via the type of teaching. In accordance with the majority of pedagogical theories, specific issues in training specialists for tourism-related activities are disclosed, which include training and development 
(Kalnei \& Polyakov, 2011; Lisitzina, 2007). Analysis of studies have shown that the formation of cognitive and professional motivation is a long process associated with the development of a student's individuality as a whole, and the transition to a student-centered, truly humane education of students has proved to be very difficult in real pedagogical practice. The main problems of teaching practice are related to the poor quality of scientific and methodical work, insufficient content development of professional motivating training of students.

\section{Methodological Framework}

\subsection{Levels of Designing the Professionally Motivating Training Content for Students Majoring in "Tourism"}

Development of natural, social and cultural basis of a future specialist in "Tourism" should be carried out by the content of training having primarily a state (public) value orientation. The training content of a specialist in the specialty "Tourism" can be considered as professionally motivating, if it develops the student's professional motivation, the desire to master the profession and to fulfill the dream. Only in this case, the content of training will ensure the satisfaction of spiritual and physical needs of a young person, provide an opportunity for self-realization in a continuous tourism education (Krayevsky, 2000).

\section{PERSONAL}

\section{TOURISM ACTIVITIES}

\section{TEACHING AND LEARNING AIDS}

2. REGULATORY (standards, plans, curriculum)



Figure 1. Levels of designing the content of professional motivating training of students majoring in "Tourism"

The content of training of students majoring in "Tourism" in the region with the development of folk arts and crafts at all levels consists of four main structural elements: the cognitive experience of professional work, fixed in the form of its results - tourist knowledge; experience of carrying out the known methods of professional work - in the form of the ability to act on the model; experience of creative activity - in the form of skills to make unconventional decisions; experience of the emotional relationships - in the form of personal orientations. Since the main objective of professional motivating training is to create a professional motivation of students, the principal place in the content must belong to the last structural element capable of transmitting the relevant motivational-valuable relationship. On the other hand, first of all, the value-oriented activities of the student should be filled with the invariant content of tourism training. Subject to these conditions the content of professional and motivating training is a system in which the integration of socio-cultural and psychological aspects of professional activity provides priority development of professional education motives. 
This system has a composition (elements), structure (interelement coupling) and methodological characteristics: properties, principles of functioning and functions that are preserved not only in theory but also on all other levels of the training content in the tourism sector: regulatory, teaching and learning aids, the process of professional activities, personal. Properties of the professional motivating training content are - humanism, openness, dialogic potential, dynamism, multifunctionality, which are caused by personal, professional and motivating approach.

Among the functions of the content of professional and motivating training of students majoring in "Tourism" a special place, of course, belongs to the professional-motivating function of training in the tourism sector, which reflects the focus of tourist activity in the college on the formation of professional motivation by opening motivational capacity in the training content. The implementation of professional motivating training function in tourism enables the integration of material and formal approaches to the formation of learning content, because the professional motivation is both the result of developing training in the field of tourism, and the means of ensuring the effective acquisition of knowledge. In turn, the synthesis of the material and formal concepts in the content of training formation in the field of tourism, achieved in the implementation of the principle of professional and motivating training, helps to resolve the contradictions between the discrete qualitative and procedural parties of professional motivation (PM), between the present motivational attitudes and abilities of the student.

\subsection{Regulatory Level}

At the next level (regulatory) the idea becomes more certain of what should be taught in the course of professional and motivating training in college. The content of special training and organization of the educational process are determined by the basic professional educational program of professional education, which includes: state requirements for the content minimum and the level of graduate training; qualification requirements for graduates in the relevant specialty; curriculum (level of general theoretical conception) and curriculum documents in the specialty (Ilkevich, 2011).

State requirements for the minimum content of professional training are set out in the state educational standards (SESs). Curricula and training programs are developed by colleges on the basis of SESs and qualification requirements for graduates in the relevant specialty. The program of professional training determines the scientific content, methodical maintenance of the discipline, the titles and the main items of study units and topics, the distribution of instructional time by study units, topics and learning sessions. Based on the program the thematic plan of the discipline is developed, which is the main working document of the professional training of a teacher, as well. The thematic plan specifies the content and organization of the discipline, contains a list of educational issues, organizational guidelines for implementation and maintenance of each session. Plans for group work are compiled in accordance with the thematic plan.

\subsection{Learning and Teaching Level}

Designing the content of professional and motivational training in college majoring in "Tourism", at the level of learning and teaching aids, is carried out in the academic literature, which includes textbooks, handbooks, teacher editions, methodological recommendations, manuals, scientific and reference books, guidances and instructions and other documents. Literature is created in college during a scientific and methodical work. In the literature on specialty "Tourism" the material is divided into separate topics and its actual presentation is given. There are elements of the training content in the field of tourism specified, which are marked on the first level and presented in the second in a form specific for the training in the field of tourism. Methodical aids are an aid to teachers and students in the organization of training in the "Tourism" specialty both in the classroom and in personal time (see the Annex) (Ilkevich \& Sukhodolova, 2011).

Literature on the special training provides self-motivated, conscious and active professional activities of students. Most of the used textbooks well enough exercise informational and controlling corrective function. The manuals detail the contents of the main elements of a tourist job. In accordance with the principle of professionally motivating training (PMT) to the content of teaching and learning aids, which is used in the preparation for the specialty "Tourism", the following requirements must be met: 1) teaching and learning aids should be professionally but not discipline directed; 2) the material must be entertaining, show achievements, create new experiences for students, give rise to reflections and a surprise. In this case, students are faced with the contradictions between the perceived knowledge about the preparation and own life and professional experience that encourages them to think and arouses interest to the training sessions; 3 ) the information content of the material should be consistent with existing and emerging needs; 4) the content of teaching and learning aids should be available to students, to the best of their knowledge, from professional and life experience, should be 
built on that. At the same time the material must be sufficiently complex and difficult; 5) teaching and learning aids must necessarily carry new information about tourism, in the light of which past knowledge and experience can be understood and deepened, to reveal the practical and recreational importance of the content of training in the field of tourism. In this case, the information should have enough redundancy that reduces the possibility of distortion in its transmission and perception, facilitates the preservation of attention span; 6) the content of the teaching aids should be directed to the formation of a professional style of thinking, dialectical generalization of knowledge in the field of tourism training, mastery of the general methods of scientific knowledge.

\subsection{Tourist Activity and Personal Level}

In fact, the content of training of students majoring in "Tourism" is inseparable from the tourist activity. On the one hand, the training of students majoring in "Tourism" is in the transfer by a teacher and in students' learning to understand the content of a particular element, on the other - the content is communicated to the student only during the tourist activity and only exists really in it.

We can say that if we are talking about the rationale, design and construction of the content of professional and motivational training (first three stages of the content construction), the training of specialists in the specialty "Tourism" - is a science -tourist pedagogics. At the same time the tourist pedagogics is a kind of art, because the teacher will never reach the proper pedagogical effect without the inclusion of the personal vision of ways to implement the professional motivating content of the training in the tourism sector in the fourth and fifth stages of its formation. When forming the content of professional and motivating training, creativity is needed, taking into account the purpose of formation of motivational sphere of tourist activity, the degree of formation of the students' professional and general tourist motivation work. The content of professional and motivating training is refracted through the personality of the student and transformed because of its motivational value orientation. Personal, emotional and value student experience is necessarily present in the structure of the training content in the tourism sector as a specific component. Creative approach to conduct motivating professional training in the tourism sector requires additional time-consuming at first, but further development of motivation will allow the student to set goals, to separate the important from the unimportant, look for different ways to achieve a high level of preparedness.

\section{Results and Discussions}

To the curricula, given the focus of the Institute - folk arts and crafts, we have included the following disciplines:

- The history of Gzhel craft

- Organization of the ceramic production industry technology

- Museology

- Service of excursionists and tourists (in Gzhel)

- Animation activities (meeting excursionists and tourists in Gzhel)

- Hospitality Industry

Special units devoted to the study of Gzhel region singularities are included in the curriculum documents of certain disciplines. For example, the discipline of "Tourist Regional Studies of Russia" examines tourist Gzhel resources, students design creative projects, develop tourist routes (Annex "Gzhel Tours"). At the end of the discipline "Tourist Regional Studies of Russia" a Student Tourist Exhibition "Gzhel: tourism, sport, rest" is held (Annex). Students under the guidance of teachers develop tourist routes, study and describe the Gzhel infrastructure, provide information about the development of tourism in Gzhel, offer animation programs, etc.

Study of the discipline "Excursion activity" helps students conduct tours around Gzhel State Art and Industry Institute for high school students and college students, to develop their excursions for tourists coming to Gzhel (Annex).

Discipline "Hospitality Industry" provides practical training in hotels, boarding houses, holiday centers. A separate section of the discipline is devoted to the characteristics of meeting and accommodating tourists in Gzhel.

In the content of the curriculum the study units forming the interests of students are included, motivating them to study in the direction of the development of skills and abilities for professional activity.

Students enrolled in the specialty "Tourism" should be prepared for the professional delivery of services in the tourism sector, as a specialist in tourist services, including the tour operator and travel agent. 
Table 1. Curriculum for students majoring in "Tourism" in the region with the developed folk arts and crafts

\begin{tabular}{ll}
\hline General disciplines & Russian Language, Literature, Foreign Language, History, Social Studies, Geography, \\
& Mathematics, Computer Science, Physics, Chemistry, Physical Education, Biology, Life \\
& Safety, Ecology, Introduction to the profession
\end{tabular}

Common humanitarian Fundamentals of Philosophy, Fundamentals of Law, Russian language and culture of and socio-economic speech, Foreign Language, Physical Education, Fundamentals of Economics disciplines

Elective courses
established by the
educational institution

\begin{tabular}{ll}
\hline $\begin{array}{l}\text { Mathematical and } \\
\text { general natural sciences }\end{array}$ & Mathematics, Informatics, Ecological bases of nature \\
\hline $\begin{array}{l}\text { General professional } \\
\text { disciplines }\end{array}$ & $\begin{array}{l}\text { Service activities, Standardization and Certification of tour services, records } \\
\text { management, foreign language (professional), Tourism Management, Tourism } \\
\text { Marketing, Geography of Tourism, Tourist Regional Studies of Russia, Legal regulation } \\
\text { of tour activity, Ethics and psychology of business communication, Legal Support of } \\
\text { professional activity, sector economics, Health and Safety }\end{array}$ \\
\hline
\end{tabular}

Special disciplines $\quad$ Organization of tourism, technology and organization of tour operator and travel agent activities, organization of domestic tourism, hospitality industry, organization of transport services in tourism, excursion activities, Information technologies in professional activities

\begin{tabular}{|c|c|}
\hline $\begin{array}{l}\text { Elective courses } \\
\text { established by the } \\
\text { educational institution }\end{array}$ & $\begin{array}{l}\text { History of Gzhel crafts, organization of ceramic industry technology, Logic, Museology, } \\
\text { Computer career support }\end{array}$ \\
\hline Opt & $\begin{array}{l}\text { hysical Education, Foreign Language, Servicing tourists, Country studie } \\
\text { ctivities }\end{array}$ \\
\hline
\end{tabular}

When developing the curriculum for practice (practice for the first skills - 2 weeks, the major practice - 4 weeks, pre-graduation practice (qualification) - 4 weeks) regional peculiarities of Gzhel were taken into account. Gzhel infrastructure consists of companies that provide traineeships for students. A future specialist in tourist services is trained from scratch. Students work in production workshops - learn craftsmanship of Gzhel products. This enhances the process of transformation from cognitive motives to professional motives.

Discipline "History of Gzhel craft" as an elective discipline, has been established by the institution in reliance on the regional peculiarities of Gzhel, and enhances professional motivation of students.

Academic discipline "Introduction to the profession" helps students understand the nature, functions and structure of professional training, the process of formation and professional features of a specialist in tourism services. The main objectives of the discipline are as follows: To familiarize students with the basic provisions of the state requirements of state educational standards in the specialty "Tourism"; provide systematic knowledge in the discipline; develop in students a firm belief in the need of thorough preparation for the professional activity; contribute to the formation of skills of independent work with reference books and other sources of information in the field of tourism; adjust students to the possibility of mastering one of the related occupations: Agent for Tourism, the organizer of tourist groups, Secretary, computer operator, etc.

\section{Conclusion}

The content of professional education reveals a set of subjects to be studied and those that make up the program of professional and motivating training of students majoring in "Tourism". The content of the curriculum includes study units forming the interests of students, motivating them to study in the direction of the development of skills and abilities of professional activity.

The content of professional and motivating training depends on the action of general pedagogical and specific factors and conditions that determine both general and specific features of it. Taking into account the regional 
characteristics that determine professional motivation, the designed content for training students majoring in "Tourism" in the region with the developed folk arts and crafts, can be implemented in other institutions which have "Tourism" specialty, as well.

The content of the training in the "Tourism" specialty can be considered as professional and motivating, as it develops the student's professional motivation, the desire to master the profession and to fulfill the dream. It provides satisfaction of the spiritual and physical needs of the young person, provides an opportunity for self-realization in the system of continuous tourism education in the region with the developed folk arts and crafts.

\section{References}

Bugrimenko, A. G. (2006). Internal and external training motivation of students of pedagogical high school. Psychological Science and Education, 4, 34-37.

Dubovitskaya, D. (2003). On the problem of diagnosis of learning motivation. Questions psychology, 3, 73-78.

Gribenyuk, O. S., \& Gribenyuk, T. B. (1998). Introduction to the work of the teacher-researcher (p. 57). Kaliningrad.

Ilkevich, B. V. (2011). Problems and Prospects of Industrial Arts Education. Pedagogy, 6, 80-88.

Ilkevich, B. V., \& Sukhodolova, E. P. (2011). Industrial Art Education in Gzhel. Higher education today, 3, 58-61.

Ilkevich, B. V., \& Ilkevich, K. B. (2013). Vocational and motivational art-industrial education (p. 204). Gzhel. GGHPI Press.

Ilyin, E. P. (2002). Motivation and motifs (p. 512). Saint Petersburg.

Ilyin, E. P. (2004). Motivation and motives. St. Petersburg.

Kal'nei, V. A., \& Polyakov. A. V. (2011). Diagnostic assessment methodology training of tourist high school students to develop professional presentations of tourist products. Khimki: RIAT. Guidelines for Teachers.

Khan, Z. N. (2009). Cognitive and Non-Cognitive Characteristics as Determinants of Success in Professional Courses at Undergraduate Stage. J. Soc. Sci., 5, 212-215.

Kibanov, A. J., Batkaeva, I. A., \& Gagarin, G. P. (2001). Motivation of work: Textbook (p. 77). Samara.

Krayevskiy, V. V. (2000). The content of education - running in place. Pedagogy, 7, 3-12.

Lisitzina, T. B. (2007). Vocational and motivational training of students majoring in "Tourism" in the conditions of the region (p. 210). Thesis. Kazan.

Popov, V. A., \& Kondratyeva, O. Y. (1999). Changing the motivational value orientations of students. Sociological Studies, 6.

Sorokina, N. (2003). Socio-psychological training of professional self-motivation: The method recommendations (p. 75). Tula University.

Valeev, T. I., \& Shaft, T. I. (2003). Formation of the structure of professional motivation of students (p. 54). Izhevsk.

Verbitsky, A. A., \& Bakshaeva, N. A. (1998). Development motivation in learning context. Herald high school $1(2), 47-50$.

Vishtak, O. V. (2003). Motivational preferences of applicants and students. Sociological Studies, 2.

Zhdanova L. G. (2012). Psychological problems of the period of youth: A teaching aid. Samara (p. 116). PGSGA Press.

\section{Copyrights}

Copyright for this article is retained by the author(s), with first publication rights granted to the journal.

This is an open-access article distributed under the terms and conditions of the Creative Commons Attribution license (http://creativecommons.org/licenses/by/3.0/). 